\title{
High School Students' Attitudes towards Mathematics and Factors Affect Their Attitudes in Turkey*
}

\author{
Metin YAŞAR ${ }^{* * *}$ Hülya ÇERMÍK ${ }^{* * *}$ Necdet GÜNER *****
}

\begin{abstract}
The aim of this study was to examine the level of Turkish high school students' attitudes towards mathematics and to determine the factors affecting their attitudes. Also, it was aimed to explore the relationship between the gender and geographical regions of students with their attitudes towards mathematics. The research performed using by the survey model was conducted on 30170 students from different types of high schools at 14 cities in seven geographic regions of Turkey. The mathematics attitude scale developed by researchers was administered to these high school students. The results indicated that Turkish high school students had attitudes toward mathematics at moderate level and students' gender had no impact on their attitudes. However, there was a significant difference between students' geographical regions and their mathematics attitudes.
\end{abstract}

Keywords: Mathematics, attitude, high school student, gender, geographical regions.

\footnotetext{
This study was supported by Pamukkale University, Scientific Research Project Coordination Unit, Project Number: 2006EĞT003.

** Assist. Prof. Dr., Pamukkale University, Faculty of Education, Department of Educational Sciences. E-mail: myasar@pau.edu.tr

Assoc. Prof. Dr., Pamukkale University, Faculty of Education, Department of Primary Education. E-mail: hcermek@pau.edu.tr

${ }^{* * * *}$ Assoc. Prof. Dr., Pamukkale University, Faculty of Education, Department of Primary Education. E-mail: nguner@pau.edu.tr
} 


\section{SUMMARY}

Purpose and Significance: In the international competition of the new global world, every nation needs more talented people who are capable of modeling, decision-making and managing data. Acquiring these skills emphasizes the importance of mathematics. In Turkish context it can be said that there has been studies about finding out the level of students' attitudes towards mathematics and the factors affecting students' attitudes. However, there has not been conducted any studies with high school students aiming to examine their attitudes towards mathematics and variables affecting these attitudes considering the broad sampling in Turkey. High school level is the step of both reaching the university level and choosing the career. Therefore, it is significant to determine high school students' attitudes towards mathematics and to find out the relationship between the variables as student's gender and the geographical regions they live and their attitudes towards mathematics.

Method: In this research survey method was used. The researchers developed the mathematics attitude Likert-type scale which was consisting of 35 items. The reliability of the scale was measured as .9413 based on Cronbach Alfa coefficient. The survey was conducted with 30170 students in ten different types of high schools. Fourteen cities, which were Ankara, Antalya, Bursa, Denizli, Diyarbakır, Elazığ, Erzurum, Eskişehir, Isparta, İstanbul, İzmir, Mardin, Samsun, and Uşak were selected from seven geographic regions.

Results: The results of this research showed that the level of Turkish high school students' attitude toward mathematics was at moderate level. Also, there were no statistically significant effects of students' gender on their attitudes toward mathematics. On the other hand, there was a significant difference between students' attitudes towards mathematics and the geographical regions where they lived. The results indicated that high school students from South-Eastern and Eastern Anatolian regions had the lowest average of mathematics attitude whereas students from Aegean region had the highest average of mathematics attitude.

Discussion and Conclusions: The result of this study showed that high school students have moderate level of attitudes towards mathematics. The students' attitudes to mathematics had a relation with their geographical region. This also indicated that students from low socio-economical region had negative mathematical attitudes. Studies done in different countries emphasized that students' successes were related with the value given to the education by the government. This study was done to determine students' attitudes towards mathematics. Another study can be done to find out factors affecting students' attitudes in mathematics with their reasons. 


\title{
Türkiye’deki Lise Öğrencilerinin Matematik Dersine İlişsin Tutumları ve Bu Tutumlarını Etkileyen Faktörler*
}

\author{
Metin YAŞAR ${ }^{* *}$ Hülya ÇERMIK ${ }^{* * *}$ Necdet GÜNER
}

\begin{abstract}
ÖZ. Bu araştırmanın amacı, Türkiye'de öğrenim gören lise öğrencilerinin matematik dersine ilişkin tutum düzeylerinin belirlenmesi ve bu tutumlarını etkileyen faktörlerin ortaya koyulmasıdır. Ayrıca araştırmada, öğrencilerin cinsiyetleri ile öğrenim gördükleri coğrafi bölgenin de matematik dersine ilişkin tutumlarında anlamlı bir farklılık yaratıp yaratmadığı araştırılmıştır. Tarama modelinde gerçekleştirilen bu araştırma, yedi coğrafi bölgedeki 14 ilde bulunan, farklı türdeki liselerde öğrenim gören toplam 30170 öğrenci üzerinden yürütülmüştür. Araştırmaya katılan lise öğrencilerine, araştırmacılar tarafından geliştirilen Likert türündeki bir tutum ölçeği uygulanmıştır. Araştırma sonucunda, Türkiye'deki lise öğrencilerinin matematik dersine ilişkin tutumlarının orta düzeyde ve dört faktöre dayalı olduğu belirlenmiştir. Öğrencilerin matematik dersine ilişkin tutumları cinsiyetlerine göre değişmezken, öğrenim gördükleri coğrafi bölgeye göre anlamlı farkl1lıklar göstermektedir.
\end{abstract}

Anahtar Sözcükler: Matematik, tutum, lise öğrencisi, cinsiyet, coğrafi bölge.

\footnotetext{
Pamukkale Üniversitesi BAP Birimi tarafından desteklenen 2006EĞT003 nolu araştırma projesinden derlenmiștir.

** Yrd. Doç. Dr., Pamukkale Üniversitesi Eğitim Fakültesi Eğitim Bilimleri Bölümü. E-posta: myasar@pau.edu.tr

*** Doç. Dr., Pamukkale Üniversitesi Eğitim Fakültesi İlköğretim Bölümü. E-posta: hcermek@pau.edu.tr **** Doç. Dr., Pamukkale Üniversitesi Eğitim Fakültesi İlköğretim Bölümü. E-posta: nguner@pau.edu.tr
} 


\section{GİRIŞ}

Yaşadığımız yüzyılda bir ulusun sahip olduğu kuramsal ve sistematik bilgiler, bilimsel ve teknolojik gelişmelerin temelini oluşturmaktadır. $\mathrm{Bu}$ durum bilim ve teknoloji çağı olan günümüzde matematiğin önemini de sürekli olarak arttırmaktadır. Çünkü matematik, günümüzün gelişen dünyasında, bilim ve teknoloji için vazgeçilmez bir anahtardır. Matematik, bilgiyi işlemeyi, üretmeyi, tahminlerde bulunmayı ve bu dili kullanarak problem çözmeyi içerir (MEB, 2009). Bununla birlikte neden-sonuç ilişkisi kurarak günlük yaşamda karşılaşılan sorunları çözebilmemizde de matematiğin katkısı büyüktür. Matematiğin bu denli önemli olması, elbette öğrencilerin matematik dersinde başarılı olma isteklerini de beraberinde getirir. Ancak öğrenciler matematik derslerine ilişkin oluşturdukları olumsuz önyargılar nedeniyle zorlanmakta, bu derslerden korkmakta, kaygı duymakta ve sonucunda akademik anlamda başarısız olmaktadırlar (Alkan, 2009). Perry (2004) tarafindan yapılan bir araştırmada da matematik öğretmenlerinin, matematik kaygısının öncelikle öğrencilerin başarısızlık korkularından ve derste kendilerini yetersiz hissetmelerinden kaynaklandığ 1 konusunda hemfikir oldukları vurgulanmaktadır. Bu durum matematiğin öğrenilmesinde belirleyici faktörlerin başında öğrencilerin matematiğe yönelik geliştirdikleri tutumu akla getirmektedir. Çünkü tutum , "bir nesneye, olguya, kavrama veya kişiye karşı, daha önceden edinilmiş pozitif veya negatif duygu, düşünce ve davranışların bütünü” (Aiken, 1970: 551) olarak tanımlanmaktadır. Bireyin bir nesne, durum ya da kişi hakkında zihinsel, duygusal ve davranışsal anlamda ortaya koyduğu duruş onun tutumunu yansitır (İnceoğlu, 2010). Benzer şekilde matematik dersine yönelik tutum da "matematiğe karşı oluşmuş olumlu veya olumsuz duygu, düşünce ve davranışlar" (Zan ve Di Martino, 2007:158) dır. Bu bakımdan öğrencilerin matematik dersine ilişkin tutumlarının, matematik eğitiminde önemli bir yeri olduğu söylenebilir.

Matematiğe ilişkin tutumu belirleyebilmek amaciyla farklı ülkelerde birçok araştırma yapılmıştır. Örneğin, öğrencilerin matematik tutumlarını ölçmek üzere Aiken (1974) tarafından, 23 maddeden oluşan beşli Likert tipi bir ölçek geliştirilmiştir. Bu ölçek matematikten hoşlanma ve matematiğin değeri şeklinde adlandırılan iki alt faktöre sahiptir. Aynı amaçla geliştirilen Fennema-Sherman matematik tutum ölçeği de (Fennema ve Sherman, 1976) dokuz alt faktöre sahip, 108 maddeden oluşan beşli Likert tipi bir ölçektir. Fennema-Sherman Ölçeği, Mulhern ve Rae (1998) tarafından kısaltılarak da kullanılmıştır. Bunların dışında, son yıllarda geliştirilen matematik tutum ölçeklerine de rastlamak mümkündür (Adelson ve McCoach, 2011; Tapia ve Marsh, 2004). Adelson ve McCoach (2011) tarafindan geliştirilen ölçek beşli 
Likert tipinde olup 27 maddeden ve matematik öz alg1sı ile matematikten zevk alma olmak üzere iki faktörden oluşmaktadır. Tapia ve Marsh (2004) tarafindan geliştirilen, 49 maddelik beşli Likert tipi matematik ölçeği ise dört faktöre sahiptir ve bu faktörler; özgüven, değer, keyif alma ile motivasyon olarak adlandırılmıştır.

Yapılan araştırmaların bir kısmı matematik dersi başarısı ile matematik tutumu arasındaki ilişkiyi ortaya koymayı amaçlamıştır (Ethington ve Wolfle, 1986; Feather, 1988; Ma, 1997; Ma ve Kishor,1997; Meece, Wigfield ve Eccles, 1990; Minato ve Kamada,1996; Quinn ve Jaday, 1987; Wilkins ve Ma, 2003). Bunlardan Ethington ve Wolfle (1986) ile Ma (1997) tarafından yapılan araştırmalarda, matematik tutumu yüksek olan öğrencilerin matematik dersinde daha başarılı oldukları anlaşılmıştır. Minato ve Kamada (1996) ile Ma ve Kishor'un (1997) birbirlerinden bağımsız olarak yaptıkları meta analiz çalışmalarında, matematik tutumunun matematik başarısı üzerinde tek yönlü etkisi olduğu sonucuna ulaşılmıştır. Ancak matematik tutumu ile matematik başarısının birbirini iki yönlü etkilediği şeklinde görüş bildiren çalışmalar da bulunmaktadır (Feather, 1988; Meece, Wigfield ve Eccles, 1990; Quinn ve Jaday, 1987). Ayrica Wilkins ve Ma (2003) tarafından yapılan bir araştırmada 3116 öğrenci, 6. sınıftan 12. sınıfa kadar izlenmiş, öğrencilerin lisede matematiğe karşı daha olumsuz bir tutuma sahip oldukları görülmüştür. Alandaki araştırma sonuçlarına dayalı olarak matematik tutumu ile matematik başarısı arasındaki ilişkinin oldukça karmaşık bir yapıya sahip olduğu söylenebilir.

Öğrencilerin matematik dersine ilişkin tutumlarının bazı değişkenler açısından incelendiği çalışmalar da bulunmaktadır. Örneğin, Brandell ve Staberg (2008), Farooq ve Shah (2008), Hoang (2008), Muzzatti ve Agnoli (2007) ile Owiti (2011) tarafından yapılan araştırmalarda matematik tutumu ile öğrencilerin cinsiyetleri arasında bir ilişki olup olmadığı sorgulanmıştır. İtalya'da Muzzatti ve Agnoli (2007) tarafından gerçekleştirilen araştırmada, hem kız hem de erkek öğrencilerin ilköğretimden orta öğretime doğru ilerledikçe matematik çalışmanın gittikçe zorlaştığını düşündükleri ortaya çıkmıştır. Okula yeni başlayan altı ve yedi yaş grubundaki kızlar, matematik konusunda kendilerini erkek öğrencilerden daha iyi görürken, bu durum 1213 yaşına geldiklerinde tersine dönmektedir. Bu sonuçların elde edilmesinde sosyal çevrenin etkisi olduğu yönündeki görüşlerini, araştırmacılar raporlarında belirtmişlerdir. İsveç’te yapılan bir araştırmanın (Brandell ve Staberg, 2008) sonuçları, matematikten genelde erkeklerin hoşlandığını ve gelecekleri için matematiğin önemli olduğunu düşündüklerini göstermiştir. Lise öğrencilerinin matematik tutumlarının araştırıldığı ve Kenya'da yürütülen çalışmanın (Owiti, 2011) sonuçlarında ise, kız öğrencilerin matematik tutumlarının erkek öğrencilerin tutumlarından daha düşük olduğu 
bulunmuştur. Amerika Birleşik Devletleri'nin Los Angeles şehrindeki bir lisede öğrenim gören öğrencilerin matematik dersine karşı tutumlarının araştırıldığ biraz daha olumlu tutuma sahip olduklarını ancak bu farklılığın çok büyük olmadığını göstermektedir (Hoang, 2008). Diğer taraftan Pakistan'ın Lahor kentindeki 10. sınıf öğrencileri üzerinde yürütülen bir çalışmada ise, kız ve erkek öğrencilerin matematik tutumları karşıllaştırılmış ve öğrencilerin matematik tutumları ile cinsiyetleri arasında bir bağ bulunmadığı sonucuna varılmıştır (Farooq ve Shah, 2008).

Türkiye'de yapılan araştırmalarda öğrencilerin matematiğe yönelik tutumlarını belirleyebilmek için geliştirilen tutum ölçekleri (Aşkar, 1986; Baykul, 1990; Duatepe ve Çilesiz, 1999; Erol, 1989) kullanılarak farklı araştırmacılar tarafından yürütülen çalışmalar bulunmaktadır. Örneğin, Aşkar (1986) tarafından geliştirilen ve 20 maddeden oluşan Likert tipindeki Matematik dersine yönelik tutum ölçeği kullanılarak bir dizi araştırma yürütülmüştür (Avc1, Coşkuntuncel ve İnand1, 2011; Kurbanoğlu ve Takunyac1, 2012; Peker ve Mirasyedioğlu, 2003). Bu araştırmalardan lise ikinci sınıf öğrencilerinin matematik dersine yönelik tutumları ile başarıları arasındaki ilişkinin incelendiği ve Ankara ilinde sekiz lisede öğrenim gören 500 öğrenci üzerinde yapılan çalışma sonuçlarına göre, öğrencilerin yarıdan fazlasının matematik dersine yönelik olumlu tutuma sahip oldukları saptanmıştır (Peker ve Mirasyedioğlu, 2003). Bir diğer araştırma ise Mersin ili Tarsus ilçesinde 835 lise öğrencisi üzerinde yürütülmüş olup, öğrencilerin matematik tutumlarının orta düzeyde olduğu ve cinsiyetleri ile matematik tutumları arasında anlamlı bir fark olmadığı sonucuna ulaşı1mıştır (Avc1, Coşkuntuncel ve İnand1, 2011). Benzer şekilde Sakarya ili Hendek ilçesinde yürütülen bir diğer araştırmada (Kurbanoğlu ve Takunyacı, 2012) da öğrencilerin cinsiyetleri ile matematik tutumları arasında anlamlı bir fark saptanmamıştır. Baykul (1987) tarafından yapılan çalışmada, ilkokuldan itibaren öğrencilerin matematiğe karşı olumsuz tutum geliştirdikleri ifade edilmektedir. Ayrıca Baykul (1990) tarafından geliştirilen 30 maddelik Likert tipi olan matematik tutum ölçeğini ile 408 yatılı öğretmen okulu öğrencisi üzerinde yürütülen bir araştırmada (Yenilmez ve Ö̉zabacı, 2003) öğrencilerin cinsiyeti ile matematik tutumları arasında bir ilişki gözlenmemiş, öğrencilerin sınıf düzeyleri arttıkça matematik tutum ortalamalarının düştüğü belirlenmiştir. Duatepe ve Çilesiz (1999) tarafından geliştirilen ve dört faktörden oluşan (ilgi ve sevgi, korku ve güven, meslek ve önem ile zevk almak) matematik tutum ölçeği kullanılarak yapılan bir çalışmada (Kaplan ve Kaplan, 2006), Erzurum il merkezinde öğrenim gören lise öğrencilerinin cinsiyetleri ile matematik tutum ortalamaları arasında bir farklılık görülmemiştir. Erol (1989) tarafindan geliştirilen matematik tutum ölçeği kullanılarak, İstanbul ilindeki 10 lisede 656 öğrenci üzerinde 
yürütülen çalışmada, öğrencilerin matematik tutumlarının orta düzeyde olduğu ve kız öğrencilerin matematik tutumlarının erkek öğrencilerin matematik tutumlarından daha olumlu olduğu belirlenmiştir (Özlü, 2001). Benzer olarak, Yenilmez'in (2007) Eskişehir'de 593 lise öğrencisi üzerinde yaptığı araştırmada, lise öğrencilerinin matematik tutumlarının orta düzeyde olduğu ve kız öğrencilerin tutumlarının, erkek öğrencilerin tutumlarından daha pozitif olduğunu ifade edilmektedir.

2003 TIMSS (Trends in International Mathematics and Science Study: Uluslararası Matematik ve Fen Eğilimleri Araştırması) ve PISA (Program for International Student Assessment: Uluslararası Öğrenci Değerlendirme Programı) uygulamalarına katılan 69 ülke ve yaklaşı 500 bin öğrencinin verileri kullanılarak yapılan bir meta analiz çalışmasında (Else-Quest, Hyde ve Linn, 2010) matematik başarısının, bazı ülkelerde öğrencilerin cinsiyetine göre farklılık gösterdiği, bazı ülkelerde ise bu farkın hemen hemen ortadan kalktığı ifade edilmektedir. Ayrıca öğrencilerin matematik tutumları ile sosyo-ekonomik düzeyleri arasında da bir ilişki söz konusudur. Yapılan araştırmalar, öğrencinin ailesinin veya yaşadığı ülkenin ekonomik durumu iyileştikçe, TIMSS ve PISA gibi uluslararası sınavlardaki başarılarının arttığını ve matematik tutumlarının yükseldiğini de göstermektedir (Chiu ve Xihau, 2008; Dinçer ve Uysal, 2010). OECD tarafindan yapılan ve toplam 65 ülkeden 15 yaş grubu öğrencilerinin katıldığı 2012 PISA uygulaması sonuçlarına göre, Türk öğrencilerinin yaklaşı yarısı matematik öğrenmeye ilişkin negatif tutuma sahiptir (OECD, 2013).

Yapılan alanyazın taramasında, ülkemizde bu güne kadar lise öğrencilerinin matematik dersine ilişkin tutumlarını etkileyen faktörlerin neler olduğu ve öğrencilerin matematik dersine ait tutumlarının değişkenlerle olan ilişkisinin incelendiği görülmektedir. Bununla birlikte yürütülen araştırmaların bir şehir, bir veya bir kaç okul ya da belli bir okul tipi ile sınırlı olduğu ve Türkiye evrenini temsil edecek genişlikte çalışmalar yürütülmediği dikkatleri çekmektedir. Oysa lise kademesi, öğrencilerin yükseköğrenime geçişlerinde bir basamak olmakla beraber meslek seçimlerinde de etkili bir aşamadır. Bu nedenle araştırmada, Türkiye'de öğrenim gören lise öğrencilerinin matematik dersine ilişkin tutumlarını belirleme amacına dayalı olarak aşağıda yer alan sorulara cevap aranmaktadır.

(1) Türkiye'de öğrenim gören lise öğrencilerinin matematik dersine ilişkin tutumları hangi düzeydedir?

(2) Türkiye'de öğrenim gören lise öğrencilerinin matematik dersine ilişkin tutumlarını etkileyen faktörler nelerdir?

(3) Türkiye'de öğrenim gören lise öğrencilerinin matematik dersine ilişkin tutumları; öğrencilerin (i) cinsiyetlerine, (ii) öğrenim gördükleri coğrafi bölgeye göre anlamlı bir farklılıklar göstermekte midir? 


\section{YÖNTEM}

\section{Araştırmanın Modeli}

$\mathrm{Bu}$ araştırma, Türkiye'de öğrenim gören lise öğrencilerinin matematik dersine ilişkin tutum düzeyleri ile bu tutumlarını etkileyen faktörlerin neler olduğunu ortaya çıkarma amacına dayalı, tarama modelinde betimsel bir çalışmadır. Betimsel çalışmalar, çalışılan olguya ilişkin nitelikleri adından da anlaşılacağı gibi betimleme amacıyla yürütülür (Borg, Gall ve Gall, 1993). Tarama modelinde, bir grubun var olan ve sürmekte olan belirli özelliklerini saptayabilmek için verilerin toplanmasını amaçlanır (Büyüköztürk, Çakmak, Akgün, Karadeniz ve Demirel, 2008), örneklemde bulunan bireylerin tutumları, görüşleri veya davranışları açığa çıkarılmaya çalışılır (Creswell, 2008).

\section{Evren ve Örneklem}

Araştırmanın evreni 2007-2008 öğretim yılında, Türkiye genelindeki liselerde öğrenim gören öğrencilerin tümüdür. Araştırma örnekleminin belirlenmesinde, üzerinde çalışılan grubun tüm ilgili niteliklerini yansıtma olasılığını yükseltmeyi amaçlayan maksimum çeşitlilik örneklem yöntemi (Patton, 2002) kullanılmıştır. Bu aşamada öncelikle Türkiye evrenini temsil edebilmesi amaciyla yedi coğrafi bölgenin her birini kapsayacak şekilde toplam on üç il seçkisiz olarak belirlenmiştir. Ardından, araştırma grubunun Denizli il merkezinde görev yapması ve uygulama kolaylığı sağlaması açısından Denizli ili de araştırmaya dâhil edilmiştir. Bu kapsamda araştırmanın örnekleminde, Akdeniz Bölgesi'nden Antalya ve Isparta, Doğu Anadolu Bölgesi'nden Erzurum ve Elazığ, Ege Bölgesi'nden Denizli, İzmir ve Uşak, Güneydoğu Anadolu Bölgesi'nden Diyarbakır ve Mardin, İç Anadolu Bölgesi'nden Ankara ve Eskişehir, Karadeniz Bölgesi'nden Samsun ile Marmara Bölgesi'nden Bursa ve İstanbul illeri yer almaktadır. Ayrıca örneklemin belirlenmesinde il merkezlerinde bulunan tüm lise türlerinin temsil edilmesini sağlayacak düzenlemeler de dikkate alınmıştır. $\mathrm{Bu}$ nedenle araştırmanın örnekleminde Türkiye'deki 14 ilde bulunan 10 farklı lise türü (Anadolu Güzel Sanatlar Lisesi, Anadolu Öğretmen Lisesi, Anadolu Lisesi, Anadolu İmam Hatip Lisesi, İmam Hatip Lisesi, Genel Lise, Sosyal Bilimler Lisesi, Endüstri Meslek Lisesi, Fen Lisesi, Yabanc1 Dil Ağırlıklı Lise) yer almıştır. Sonuç olarak, araştırmanın örneklemini belirlenen illerde yer alan bu liselerin 9., 10., 11. ve 12. sinıflarında öğrenim gören toplam 30170 öğrenci oluşturmaktadır. Bu öğrencilerin \%55'i kız, $\% 45$ 'i ise erkek öğrencilerdir. Örneklemde bulunan 30170 öğrenci, istatistiksel olarak evrenini temsil edecek yeterliktedir (Cohen, Manion ve Morrison, 2008). 


\section{Veri Toplama Aracının Geliştirilmesi ve Uygulanması}

$\mathrm{Bu}$ araştırmada verilerin toplanması amacıyla araştırmacılar tarafından geliştirilen "matematik dersi tutum ölçeği" kullanılmıştır. Ölçeğin hazırlanması aşamasında öncelikle araştırmacılar tarafından ilgili alan yazın taraması yapılmıştır. Daha önce geliştirilmiş matematik tutum ölçekleri (Aiken, 1974; Adelson ve McCoach, 2011; Aşkar, 1986; Baykul, 1990; Duatepe ve Çilesiz, 1999; Erol, 1989; Fennema ve Sherman, 1976; Tapia ve Marsh, 2004) incelenmiş ve iki bölümden oluşan bir taslak form hazırlanmıştır. Taslak formun birinci bölümü, katılımcıların kişisel bilgilerine (cinsiyet, sınıf düzeyi, öğrenim gördüğü coğrafi bölge, okul türü vb.) ait verileri toplama amacı taşırken ikinci bölümü ise matematiğe yönelik 52 tutum maddesinin Likert tipinde hazırlanmasıyla oluşturulmuştur. Hazırlanan taslak form önce anlam ve dil bilgisi kuralları bakımından Türkçe Eğitimi Bölümü'ndeki iki alan uzmanın görüşüne sunularak incelettirilmiştir. Uzmanların önerileri doğrultusunda gerekli düzeltmeler yapılmıştır. Daha sonra, taslak halindeki tutum maddeleri, Eğitim Programları ve Öğretim alanında üç, Psikolojik Danışmanlık ve Rehberlik alanında iki, Ölçme ve Değerlendirme alanında iki, Matematik alanında bir uzman öğretim üyesine, kapsam geçerliğini test etmek adına sunulmuş, görüşleri alınarak gerekli düzenlemeler yapılmıştır. Öğretim üyeleri, taslak halindeki tutum maddelerinin öğrencilerin matematik dersine yönelik tutumlarını bilişsel, duyuşsal ve davranışsal anlamda ölçebileceği yönünde görüş beyan etmişlerdir. Söz konusu alan uzmanlarının, taslak halindeki tutum maddelerinin, ölçülecek olan yapıya ait konuyu yeterince temsil ettiğini beyan etmeleri, ölçeğin kapsam geçerliliğine sahip olduğunu göstermektedir (Tan, 2008).

Taslak ölçeğin pilot çalışması 2006-2007 öğretim yılı bahar döneminde Denizli il merkezi ile Denizli’ye bağlı Tavas ve Honaz ilçelerinde öğrenim gören 430 lise öğrencisinin katılımıyla gerçekleştirilmiştir. Ölçekte yer alacak maddeler belirlenirken madde-toplam korelasyonu, ölçeğin iç tutarlılık anlamında güvenirliği için Cronbach Alfa Katsayısı hesaplanmıştır. Ayrıca ölçeğin yap1 geçerliliği için Açımlayıc1 Faktör Analizi gerçekleştirilmiştir. Pilot uygulamadan elde edilen verilerin analizi sonucunda, tutum ölçeğine ilişkin güvenirlik katsayısı 0.87 olarak bulunmuştur. Pilot çalışmanın ardından yapılan istatistiksel analizler sonucunda madde sayısı 41'e indirilmiştir. Elde edilen ölçek, örneklemde yer alan okullarda öğrenim görmekte olan lise öğrencilerine 2007-2008 öğretim yılı güz döneminde profesyonel anketörlerden alınan destekle uygulanmıştır. Uygulanan ölçme aracının iç tutarlılık anlamında güvenirlik katsayısını hesaplamak için madde-toplam korelasyonuna bakılmıştır. 
Analizler sonucunda, gerekli görülen durumlarda, ölçme aracından maddeler çıkarılabilir ve veriler tekrar analiz edilebilir (Büyüköztürk, 2002). Dolayısıyla iç tutarlık analizi sonucunda 41 maddeden altı maddenin toplam korelasyonu 0.30'un altında çıktığından, bu maddelere ait veriler analize dâhil edilmemiştir. Bu işlemden sonra, geriye kalan 35 maddeye ait veriler kullanılarak ölçme aracının yapı geçerliliğine sahip olup olmadığını belirlemek için Açımlayıcı Faktör Analizi gerçekleştirilmiş̧ir. Ölçekten elde edilen verilerin faktör analizine uygun olup olmadığı Kaiser-Meyer Olkin (KMO) değeri ve Bartlett Sphericity testi ile incelenmiştir. Toplam 35 maddenin faktör analizi için KMO değeri 0.967 olarak bulunmuştur. $\mathrm{Bu}$ değer, faktör analizini gerçekleştirmek için araştırmada elde edilen verilerin mükemmel derecede uygun olduğunu göstermektedir (Kalayc1, 2006). Araştırmanın Ki-Kare (Chi-Square) test istatistiği ( $\chi^{2}=487766.112$; $\mathrm{p}<0.05)$ anlamlı çıktığı için, kullanılan verilerin normal dağılım özelliğine sahip olduğunu göstermektedir. Örneklemden elde edilen verilerin normel dağılım özelliğine sahip olması belirlendikten sonra veriler üzerinde açımlayıcı faktör analizi gerçekleştirilmiştir. Ölçekte yer alan maddelere ait öz değerler ise Tablo 1'de verilmiştir.

Tablo 1. Ölçekte yer alan maddelere ait özdeğerler

\begin{tabular}{cccc}
\hline \multicolumn{4}{c}{ Açıklanan Toplam } \\
Madde No & Özdeğer & \% Varyans & \%Varyans \\
\hline 1 & 12.068 & 34.480 & 34.480 \\
2 & 2.669 & 7.626 & 42.106 \\
3 & 2.186 & 6.246 & 48.352 \\
4 & 1.265 & 3.615 & 51.967 \\
5 & 1.081 & 3.089 & 55.056 \\
6 & .908 & 2.596 & 57.652 \\
7 & .832 & 2.378 & 60.030 \\
8 & .782 & 2.235 & 62.264 \\
9 & .731 & 2.087 & 64.352 \\
10 & .720 & 2.056 & 66.408 \\
11 & .673 & 1.922 & 68.330 \\
12 & .644 & 1.840 & 70.170 \\
13 & .635 & 1.815 & 71.985 \\
14 & .628 & 1.793 & 73.778 \\
15 & .601 & 1.718 & 75.496 \\
16 & .577 & 1.649 & 77.144 \\
17 & .558 & 1.593 & 78.737 \\
18 & .524 & 1.497 & 80.235 \\
\hline
\end{tabular}




\begin{tabular}{llll}
\hline 19 & .519 & 1.483 & 81.718 \\
20 & .498 & 1.422 & 83.139 \\
21 & .489 & 1.398 & 84.537 \\
22 & .474 & 1.355 & 85.891 \\
23 & .467 & 1.335 & 87.226 \\
24 & .446 & 1.275 & 88.501 \\
25 & .429 & 1.224 & 89.725 \\
26 & .416 & 1.188 & 90.914 \\
27 & .398 & 1.138 & 92.051 \\
28 & .386 & 1.102 & 93.153 \\
29 & .383 & 1.093 & 94.246 \\
30 & .371 & 1.061 & 95.307 \\
31 & .365 & 1.044 & 96.351 \\
32 & .351 & 1.001 & 97.352 \\
33 & .345 & .987 & 98.339 \\
34 & .313 & .894 & 99.233 \\
35 & .268 & .767 & 100.000 \\
\hline
\end{tabular}

Tablo1'de görüldügü üzere, birinci maddeye ait faktör yükünün, ikinci maddeye ait faktör yükünün iki katından fazla olması, ölçme aracının tek boyutlu olduğunu göstermektedir (Gelbal,1994). Yapılan faktör analizi sonucunda ölçeğin tek boyutlu ve dört faktörlü çıktığ1 tespit edilmiştir. Faktör yük değerlerinin, dört faktör için de 0.424 ile 0.777 arasında olduğu Tablo 2'de görülmektedir.

Tablo 2. Ölçekte yer alan maddelerin faktörlere göre dağılımı ve faktör yükleri

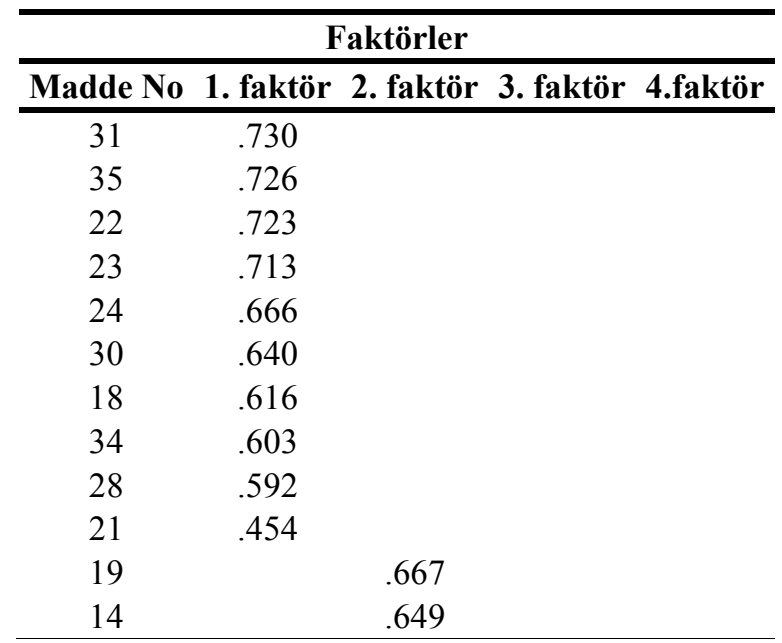




\begin{tabular}{|c|c|c|c|c|}
\hline 32 & & .643 & & \\
\hline 20 & & 639 & & \\
\hline 16 & & .626 & & \\
\hline 15 & & .614 & & \\
\hline 7 & & .596 & & \\
\hline 6 & & .561 & & \\
\hline 33 & & .542 & & \\
\hline 13 & & .429 & & \\
\hline 5 & & & .777 & \\
\hline 3 & & & .735 & \\
\hline 4 & & & .735 & \\
\hline 17 & & & .645 & \\
\hline 8 & & & .575 & \\
\hline 10 & & & .451 & \\
\hline 26 & & & .447 & \\
\hline 27 & & & .424 & \\
\hline 2 & & & & .691 \\
\hline 11 & & & & .635 \\
\hline 12 & & & & .620 \\
\hline 1 & & & & .613 \\
\hline 29 & & & & .541 \\
\hline 25 & & & & .521 \\
\hline 9 & & & & .460 \\
\hline FAÖD & 12.068 & 2.669 & 2.186 & 1.265 \\
\hline AVO & 34.480 & 7.626 & 6.246 & 3.615 \\
\hline AYVO & 34.480 & 42.106 & 48.352 & 51.967 \\
\hline$\alpha$ & .9010 & .9232 & .8877 & .8667 \\
\hline \multicolumn{4}{|c|}{ Ölçek geneli $\alpha$} & 9413 \\
\hline
\end{tabular}

Matematik dersine yönelik tutum ölçeğinin kendisi ve alt boyutlarına ait güvenirlik katsayıları hesaplanmıştır. Toplam 35 maddeden oluşan ölçeğin Cronbach Alfa güvenirlik katsayısı 0.9413 olarak bulunmuştur. Birinci ve ikinci faktörde toplam onar madde yer alırken üçüncü faktör sekiz, dördüncü faktör ise yedi maddeden oluşmaktadır. Matematik dersi tutum ölçeğinin kendisine ve dört alt faktörüne ait istatistikler Tablo 3’te verilmiştir. 
Tablo 3. Matematik dersi tutum ölçeği ile ölçeğin alt faktörlerine ait güvenirlik katsayllarl

\begin{tabular}{|c|c|c|c|}
\hline & Faktör & Faktörlere ait maddeler & $\begin{array}{c}\text { Alfa }(\alpha) \\
\text { Güvenirlik } \\
\text { Katsayısı }\end{array}$ \\
\hline 1 & Keyif alma & $18,21,22,23,24,28,30,31,34$ & .9010 \\
\hline 2 & Korku, endişe ve sıkıntı & $6,7,13,14,15,16,19,20,32,33$ & 9232 \\
\hline 3 & $\begin{array}{l}\text { Matematiğin yaşamdaki yeri, } \\
\text { önemi }\end{array}$ & $3,4,5,8,10,17,26,27$ & .8877 \\
\hline 4 & $\begin{array}{l}\text { Algılanan akademik başarı } \\
\text { Ölçek Geneli }\end{array}$ & $1,2,9,11,12,25,29$ & $\begin{array}{l}.8667 \\
.9413\end{array}$ \\
\hline
\end{tabular}

Araştırmada kullanılan ölçme aracına ait istatistikler oldukça yüksek güvenirlik ve geçerlik katsayısına sahiptir. Bu özellik ölçme aracının ölçmek istediği özelliğe karşı oldukça duyarlı olduğunu göstermektedir.

\section{Verilerin Analizi}

$\mathrm{Bu}$ çalışma kapsamında örneklemden elde edilen verilerin analizinde betimsel istatistik yöntemleri kullanılmıştır. Likert tipi olarak hazırlanan ölçekte beşli derecelendirme yapılmıştır. Aralıkların eşit olduğu varsayımından hareket edilerek, aritmetik ortalamalar için puan aralığ 1 katsayısı 0.80 olarak bulunmuştur. Puan aralığını hesaplamak için Dağılım aralığ1 = (en büyük değer - en küçük değer) / (derece sayısı), formülü kullanılmıştır (Sümbüloğlu ve Sümbüloğlu, 1993). Ölçekte yer alan olumlu maddeler 5-4-3-2-1 şeklinde, olumsuz maddelerde ise 1-2-3-4-5 şeklinde puanlanmıştır. Böylece uygulamaya dâhil olan her bir veri toplama aracının, madde puanları toplamından ölçek toplam puanı elde edilmiştir. Ölçekte elde edilebilecek en düşük puan 35, en yüksek puan ise 175 'dir. Aritmetik ortalamaların değerlendirme aralığ 1 ise; (1) 1.00-1.80 "Hiç Katılmıyorum", (2) 1.81-2.60 "Kat1lmiyorum", (3) 2.61-3.40 "Orta düzeyde kat1liyorum", (4) 3.41-4.20 "Kat1lıyorum", (5) 4.21-5.00 "Tamamen Kat1liyorum" şeklindedir.

Elde edilen veriler SPSS 11.5 (Statistical Package for the Social Sciences) programı aracılığ 1 ile belirlenen amaçlar çerçevesinde çözümlenmiş ve analiz edilmiştir. Ölçekten elde edilen verilerin çözümlenmesinde, betimsel istatistik yöntemlerine ek olarak bağımsız örneklemler için $t$ testi, ikiden fazla değişkenli gruplarda tek yönlü varyans analizi kullanılmıştır. Tek yönlü varyans analizi sonucunda, gruplar arası anlamlı düzeyde fark çıktığında, farklılı̆̆ın hangi grup veya gruplardan kaynaklandığını belirlemek amacıyla yapılan çoklu karşılaştırmalar için Fisher LSD (least significant difference) testi gerçekleştirilmiştir. Elde edilen bulgular 0.05 anlamlılık düzeyinde yorumlanmıştır. 


\section{BULGULAR}

\section{Araştırmanın Birinci Alt Problemine İlişkin Bulgular}

Araştırmanın birinci alt problemi "Türkiye'de öğrenim gören lise öğrencilerinin matematik dersine ilişkin tutumları hangi düzeydedir?" şeklinde belirlenmiştir. Bu alt probleme cevap oluşturmak amacıyla, lise ögrencilerinin ölçekte yer alan 35 maddeye verdikleri cevapların ortalaması hesaplanmış, katılma düzeyi belirlenerek Tablo 4'de sunulmuştur.

Tablo 4. Türkiye'de öğrenim gören lise öğrencilerinin matematik dersine ilişkin tutumlarina ait istatistikler

\begin{tabular}{cccc}
\hline Madde sayısı & $\mathbf{N}$ & $\bar{x}$ & Katılma Düzeyi \\
\hline 35 & 30170 & 2.74 & Orta düzeyde katılıyorum \\
\hline
\end{tabular}

Tablo 4 incelendiğinde, geniş bir örneklem üzerinde gerçekleştirilen araştırmada, Türkiye'de öğrenim gören lise öğrencilerinin matematik dersine ilişkin tutumlarının orta düzeyde olduğu belirlenmiştir.

\section{Araştırmanın İkinci Alt Problemine İlişkin Bulgular}

Araştırmanın ikinci alt problemi “Türkiye'de öğrenim gören lise öğrencilerinin matematik dersine ilişkin tutumlarını etkileyen faktörler nelerdir?" şeklinde belirlenmiştir. Bu alt probleme cevap oluşturmak amacıyla yapılan analizlerde, faktörleri oluşturan maddeler, maddelerin aritmetik ortalamaları ve standart sapma değerleri belirlenmiş ve aşağıda yer alan Tablo 5 'te sunulmuştur.

Tablo 5 incelendiğinde, lise öğrencilerinin matematik dersine ilişkin tutumlarının dört faktöre dayandığ 1 tespit edilmiştir. Bunlar, keyif alma ( $\bar{x}=3.15)$, korku, endişe ve sıkıntı $(\bar{x}=2.42)$, matematiğin yaşamdaki yeri, önemi $(\bar{x}=2.61)$ algılanan akademik başarı $(\bar{x}=2.76)$ olarak isimlendirilmiştir. Birinci faktörü oluşturan, "keyif alma" boyutu, toplam on maddeden oluşmaktadır. 
Tablo 5. Öğrencilerin matematik dersine ilişkin tutumlarına etki eden faktörler, faktörlere ait maddeler ve bu maddelerin aritmetik ortalamalart ile standart sapmalar

\begin{tabular}{|c|c|c|c|c|}
\hline & & & $\overline{\bar{x}}$ & Ss \\
\hline \multirow{10}{*}{ 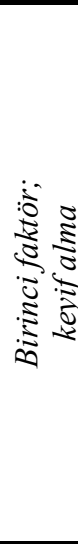 } & 34 & Matematiği kendi başıma da öğrenebileceğime inancım tam & 3.47 & 1.32 \\
\hline & 31 & $\begin{array}{l}\text { Karşılaştı̆̆ım her konuda matematiksel düşünmekten keyif } \\
\text { alıyorum. }\end{array}$ & 3.43 & 1.31 \\
\hline & 18 & Kendimi en rahat ve başarılı hissettiğim ders matematiktir. & 3.25 & 1.41 \\
\hline & 35 & Boş zamanlarımda matematik ile uğraşmaktan keyif alırım. & 3.19 & 1.40 \\
\hline & 22 & $\begin{array}{l}\text { Gördüğ̈̈m her yerde matematik problemi çözmek bana zevk } \\
\text { verir. }\end{array}$ & 3.18 & 1.37 \\
\hline & 28 & $\begin{array}{l}\text { Gelecekte herhangi bir sinavda matematikle ilgili iyi bir } \\
\text { derece yapacağıma inanıorum. }\end{array}$ & 3.05 & 1.32 \\
\hline & 24 & Matematikle ilgili araștırma yapmaktan hoşlanırım. & 3.05 & 1.33 \\
\hline & 23 & tlu hissediyorum. & 3.05 & 1.35 \\
\hline & 21 & $\begin{array}{l}\text { Matematiğin hangi durumlarda işe yarayacağını bildiğim için } \\
\text { matematik çalışıyorum. }\end{array}$ & 2.93 & 1.26 \\
\hline & 30 & Matematik dersi çok keyifli ve eğlenceli bir derstir. & 2.85 & 1.38 \\
\hline \multirow{10}{*}{ 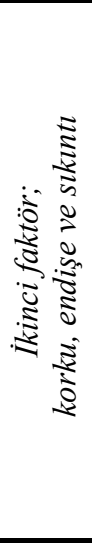 } & 6 & ok zor bir derstir. & 2.63 & 1.34 \\
\hline & 16 & $\begin{array}{l}\text { Matematik dersinin simge ve formüllerden oluşan karmaşık } \\
\text { bir ders olması beni ürkütüyor. }\end{array}$ & 2.59 & 1.33 \\
\hline & 13 & $\begin{array}{l}\text { Matematik dersinde öğrendiklerimin işime yarayacağına } \\
\text { inanmıyorum. }\end{array}$ & 2.58 & 1.37 \\
\hline & 7 & $\begin{array}{l}\text { Öğretmenlerimle matematik konularında tartışmaktan } \\
\text { çekinirim. }\end{array}$ & 2.51 & 1.24 \\
\hline & 14 & Matematik derslerinde çok sıkılıyorum. & 2.40 & 1.33 \\
\hline & 15 & Sadece dersten geçmek için matematik çalışıyorum. & 2.36 & 1.36 \\
\hline & 32 & Matematik dersi bence çok sıkıcı bir derstir. & 2.32 & 1.36 \\
\hline & 19 & $\begin{array}{l}\text { Matematik çok yoğun olarak akademik terimlerin } \\
\text { kullanıldığ sıkıcı bir derstir. }\end{array}$ & 2.32 & 1.23 \\
\hline & 20 & Matematik kendimi en başarısız hissettiğim derstir. & 2.27 & 1.40 \\
\hline & 33 & Matematik dersinden korkuyorum. & 2.22 & 1.24 \\
\hline \multirow{8}{*}{ 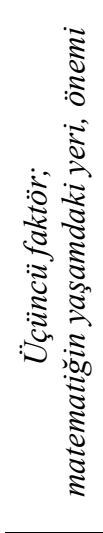 } & 17 & $\begin{array}{l}\text { Matematiğin günlük yaşantımda önemli bir yeri olduğuna } \\
\text { inanıyorum. }\end{array}$ & 2.85 & 1.34 \\
\hline & 3 & $\begin{array}{l}\text { Matematik dersinde öğrendiklerimin hayatımı } \\
\text { kolaylaştıracağına inanıyorum. }\end{array}$ & 2.84 & 1.35 \\
\hline & 5 & $\begin{array}{l}\text { Matematik dersinde edineceğim bilgilerin yaşamda işime } \\
\text { yarayacağına inanıyorum. }\end{array}$ & 2.79 & 1.34 \\
\hline & 4 & $\begin{array}{l}\text { Gelecekteki iş hayatımda matematiğe oldukça ihtiyaç } \\
\text { duyacağımı düşünüyorum. }\end{array}$ & 2. & 1.37 \\
\hline & 10 & Matematik okul dışında katkı sağlamayan bir angaryadır. & 2.57 & 1.34 \\
\hline & 26 & $\begin{array}{l}\text { Okuldan mezun olduktan sonra matematik dersinde } \\
\text { ögrendiklerimi kullanacağımı sanmıyorum. }\end{array}$ & 2.52 & 1.36 \\
\hline & 27 & $\begin{array}{l}\text { Gelecekte iyi bir iş edinebilmek için matematiği iyi } \\
\text { öğrenmek zorundayım. }\end{array}$ & 2. & 1.33 \\
\hline & 8 & Matematik bence çok önemli bir derstir. & 2.20 & 1.30 \\
\hline
\end{tabular}




\begin{tabular}{|c|c|c|c|c|}
\hline$\tilde{\xi}$ & 12 & Arkadaşlarıma göre matematikte başarılı bir öğrenciyim. & 3.03 & 1.28 \\
\hline$\frac{\sqrt{0}}{\sqrt[3]{5}} \sqrt{2}$ & 2 & $\begin{array}{l}\text { Öğretmenlerimin beni matematik dersinde başarılı bulduğuna } \\
\text { eminim. }\end{array}$ & 2.97 & 1.27 \\
\hline 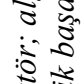 & 11 & $\begin{array}{l}\text { Matematik dersinde kendimi başarılı bir öğrenci olarak } \\
\text { görüyorum. }\end{array}$ & 2.97 & 1.29 \\
\hline$\sqrt{3}$ & 25 & Matematik dersinde iyi bir öğrenci olduğuma inanıyorum. & 2.95 & 1.32 \\
\hline$: 37$ & 9 & Matematik dersinde örnek sayılabilecek bir öğrenci değilim. & 2.72 & 1.28 \\
\hline$\sqrt[3]{3}$ & 1 & Matematik dersinde başarılı olacağıma eminim. & 2.40 & 1.27 \\
\hline$: \frac{0}{0}$ & 29 & $\begin{array}{l}\text { Matematik dersinde vasat bir öğrenci olduğumu } \\
\text { düşünüyorum. }\end{array}$ & 2.30 & 1.26 \\
\hline
\end{tabular}

Bu faktörde yer alan en yüksek aritmetik ortalama, "Matematiği kendi başıma da öğrenebileceğime inancım tam." Maddesine aittir. İkinci faktörü oluşturan, "korku, endişe ve sıkıntı" boyutu, toplam on maddeden oluşmaktadır. En yüksek aritmetik ortalamaya sahip madde, "Matematik bence çok zor bir derstir." maddesidir. Üçüncü faktörü oluşturan, "matematiğin yaşamdaki yeri, önemi" boyutunun, toplam sekiz maddeden oluştuğu görülmektedir. En yüksek aritmetik ortalama "Matematiğin günlük yaşantımda önemli bir yeri olduğuna inanıyorum." maddesine aittir. $\mathrm{Bu}$ durum öğrencilerin, matematik dersinde öğrendiklerini yaşam süreci içerisinde kullanabildiklerini akla getirmektedir. Dördüncü faktörü oluşturan, "algılanan akademik başarı" boyutu ise, toplam yedi maddeden oluşmaktadır. $\mathrm{Bu}$ faktörde yer alan en yüksek aritmetik ortalamanın "Arkadaşlarıma göre matematikte başarılı bir öğrenciyim." maddesine ait olduğu görülmektedir. Bu da öğrencilerin matematik dersinde başarısızlık korkusu ve yetersizlik hissi nedenine dayalı bir kaygı taşımadıklarını akla getirmekte olup sevindiricidir.

\section{Araştırmanın Üçünü Alt Problemine İlişkin Bulgular}

Araştırmanın üçüncü alt problemi “Türkiye'de öğrenim gören lise öğrencilerinin matematik dersine ilişkin tutumları; öğrencilerin (i) cinsiyetlerine, (ii) öğrenim gördükleri coğrafi bölgeye göre anlamlı bir farkl1l1k göstermekte midir?" şeklinde belirlenmiştir. Bu alt probleme cevap oluşturmak amacıyla lise öğrencilerinin matematik dersine ilişkin tutumları belirtilen değişkenlerin her biri için ayrı ayrı ele alınıp incelenmiştir.

(i) Türkiye'de öğrenim gören lise öğrencilerinin matematik dersine ilişkin tutumları öğrencilerin cinsiyetlerine göre anlamlı bir farklılı göstermekte midir?

Türkiye'de öğrenim gören lise öğrencilerinin matematik dersine ilişkin tutumları ile ögrencilerin cinsiyet değişkeni arasındaki farklılıkların 
araştırılması amacıyla bağımsız örneklemler için t testi yapılmıştır. Örneklemde yer alan 30170 öğrenciden, 205'i cinsiyetini belirtmediği için toplam 29965 kişi üzerinden analizler gerçekleştirilmiştir. Buna ilişkin t testi sonuçları Tablo 6'da verilmiştir.

Tablo 6. Öğrencilerinin cinsiyetlerine göre matematik dersine ilişkin tutum puanlarının ortalamalarına ait t testi sonuçları

\begin{tabular}{ccccccc}
\hline Cinsiyet & $\mathbf{N}$ & $\bar{x}$ & Ss & Sd & t & p \\
\hline Erkek & 13436 & 96.52 & 27.53 & 29963 & 1.744 & $.081 *$ \\
$\quad$ K1z & 16529 & 95.98 & 25.75 & & & \\
\hline$* \mathrm{p}>0.05$ & & & & & &
\end{tabular}

Tablo 6 incelendiğinde, cinsiyet değişkenine göre lise öğrencilerinin matematik dersine ilişkin tutum puanları arasında anlamlı bir farklılık görülmemektedir ( $\mathrm{t}=1.744, \mathrm{p}>0.05)$. Bu durumda Türkiye genelinde liselerde öğrenim gören kız ve erkek öğrencilerinin matematik dersine ilişskin tutumlarının benzer olduğu söylenebilir.

(ii) Türkiye’de öğrenim gören lise öğrencilerinin matematik dersine ilişkin tutumları öğrencilerin öğrenim gördükleri coğrafi bölgeye göre anlamlı bir farklılık göstermekte midir?

Türkiye'de öğrenim gören lise öğrencilerinin matematik dersine ilişkin tutumlar1 ile öğrencilerin öğrenim gördükleri coğrafi bölgeler arasındaki farklılıklara ilişkin elde edilen bulgular Tablo 7'de verilmiştir.

Tablo 7. Öğrencilerinin ögrenim gördükleri coğrafi bölgeye göre matematik dersine ilişkin tutum puanlarına ait istatistikler

\begin{tabular}{lccc}
\hline \multicolumn{1}{c}{ Coğrafi Bölgeler } & N & $\bar{x}$ & Ss \\
\hline Ege Bölgesi & 6389 & 99.28 & 27.41 \\
Akdeniz Bölgesi & 4099 & 98.56 & 27.27 \\
İç Anadolu Bölgesi & 4089 & 97.55 & 26.84 \\
Marmara Bölgesi & 5231 & 97.45 & 25.30 \\
Karadeniz Bölgesi & 1847 & 96.08 & 27.21 \\
Doğu Anadolu Bölgesi & 4296 & 91.40 & 25.88 \\
Güneydoğu Anadolu Bölgesi & 4219 & 89.98 & 27.01 \\
Toplam & 30170 & 96.01 & 26.89 \\
\hline
\end{tabular}

Tablo 7 incelendiğinde, Güneydoğu Anadolu Bölgesi'nde öğrenim gören öğrencilerin matematik dersine ilişkin tutumlarının en düşük $(\bar{x}$ 
$=89.98)$, Ege Bölgesi'nde öğrenim gören öğrencilerin ise en yüksek düzeyde ( $\bar{x}=99.28)$ olduğu görülmektedir. Türkiye'de öğrenim gören lise öğrencilerinin matematik tutum puanlarının, öğrencilerin öğrenim gördükleri coğrafi bölgeye göre anlamlı bir farkl11ık gösterip göstermediğini test etmek için varyans analizi yapılmış ve elde edilen sonuçlara Tablo 8'de yer verilmiştir.

Tablo 8. Öğrencilerinin öğrenim gördükleri cŏgrafi bölgeye göre matematik dersine ilişkin tutum puanlarına ait tek yönlü varyans analiz sonuçları

\begin{tabular}{lccccc}
\hline Coğrafi Bölge & Sd & KT & KO & F & p \\
\hline Gruplar arası & 6 & 360426.97 & 60071.162 & & \\
Gruplar içi & 30163 & 21461927.54 & 711.532 & 84.425 & $.000^{*}$ \\
Toplam & 30169 & 21822354.52 & & & \\
\hline *p $<0.05$ & & & & &
\end{tabular}

Tablo 8 incelendiğinde, Türkiye'de öğrenim gören lise öğrencilerinin, öğrenim gördükleri coğrafi bölgeye göre matematik dersine ilişkin tutum puanları arasındaki farkın anlamlı olduğu $[\mathrm{F}(6,30163)=84.425 ; \mathrm{p}<0.05]$ söylenebilir. $\mathrm{Bu}$ anlamlı düzeydeki farklılığın hangi coğrafi bölgelerde öğrenim gören lise öğrencileri arasında bulunduğunun belirlenmesi amaciyla çoklu karşılaştırma yapılmıştır. Çoklu karşılaştırmaya ait bulgular Tablo 9'da sunulmuştur.

Tablo 9. Öğrencilerin ögrrenim gördükleri coğrafi bölgeye göre matematik dersine iliş̧kin tutum puanlarının çoklu karşılaştırmalarına ait istatistikler

\begin{tabular}{lccccccc}
\hline Bölgeler & Ege & Akdeniz & İç Anadolu & Marmara & Karadeniz & $\begin{array}{c}\text { Doğu } \\
\text { Anadolu }\end{array}$ & $\begin{array}{c}\text { G. Doğu } \\
\text { Anadolu }\end{array}$ \\
\hline Ege & & & & & & & \\
Akdeniz & 0.7258 & & & & & & \\
İç Anadolu & $1.7308^{*}$ & 1.0050 & & & & & \\
Marmara & $1.8364^{*}$ & $1.1106^{*}$ & 0.1056 & & & & \\
Karadeniz & $3.1981^{*}$ & $2.4723^{*}$ & $1.4673^{*}$ & 1.3617 & & & \\
Doğu & $7.8852^{*}$ & $7.1594^{*}$ & $6.1544^{*}$ & $6.0487^{*}$ & $4.6870^{*}$ & & \\
Anadolu & & & & & & & \\
G. Doğu & $9.3043^{*}$ & $8.5785^{*}$ & $7.5735^{*}$ & $7.4679^{*}$ & $6.1062^{*}$ & $1.4192^{*}$ \\
Anadolu & & & & & & & \\
\hline
\end{tabular}

*Ortalamalar arasında $\mathrm{p}<0.05$ düzeyinde anlamlı fark vardır. 
Tablo 9'da Türkiye'de öğrenim gören lise öğrencilerinin öğrenim gördükleri coğrafi bölgeye göre matematik dersine ilişkin tutum puanları arasında anlamlı farklılıklar görülmektedir. En çarpıcı farklılık Güneydoğu Anadolu ve Doğu Anadolu Bölgeleri'nin diğer tüm bölgelerle olan farklılıklarıdır. Güneydoğu Anadolu Bölgesi'nde öğrenim gören lise öğrencilerinin matematik dersine yönelik tutum puanlarının ortalamaları ile diğer tüm coğrafi bölgelerde öğrenim gören lise öğrencilerinin matematik dersine ilişkin tutum puanlarına ait ortalamalar arasında anlamlı farklılık görülmektedir. Bu farklılık Güneydoğu Anadolu Bölgesi'nde öğrenim gören lise öğrencilerinin aleyhine, diğer tüm bölgelerde öğrenim gören öğrencilerin ise lehinedir. Yani Güneydoğu Anadolu Bölgesi’nde öğrenim gören lise öğrencilerinin matematik dersine ilişkin tutumları, diğer tüm bölgelerde öğrenim gören lise öğrencilerine göre anlamlı düzeyde düşüktür. Aynı şekilde Doğu Anadolu Bölgesi'nde öğrenim gören lise öğrencilerinin matematik dersine ilişkin tutum puanlarının ortalamaları ile diğer tüm coğrafi bölgelerde öğrenim gören lise öğrencilerinin matematik dersine yönelik tutum puanlarına ait ortalamaları arasında anlamlı farklılık bulunmaktadır. Bu farklılık da Güneydoğu Anadolu Bölgesi hariç, diğer tüm bölgeler için Doğu Anadolu Bölgesi’nde öğrenim gören lise öğrencilerinin aleyhinedir.

\section{TARTIŞMA ve SONUÇ}

$\mathrm{Bu}$ araştırma ile Türkiye genelinde öğrenim gören lise öğrencilerinin matematik dersine ilişkin tutumlarının düzeyi ve bu tutumları etkileyen faktörler belirlenmiştir. Aynı zamanda öğrencilerin matematik dersine ilişkin tutumlarının cinsiyetlerine ve öğrenim gördükleri coğrafi bölgeye göre anlamlı bir farklılık gösterip göstermediğinin de ortaya konulmasına çalışılmıştır.

Araştırmanın sonucunda elde edilen bulgular üç temel noktaya dikkat çekmektedir. Bunlardan ilki Türkiye'de öğrenim görmekte olan lise öğrencilerinin matematik dersine ilişkin tutumlarının orta düzeyde olduğudur. $\mathrm{Bu}$ bulgu konu hakkında yapılan bazı araştırmalarla (Avc1, Coşkuntuncel ve İnand1, 2011; Özlü, 2001; Yenilmez 2007) benzerlik göstermektedir. Ancak Peker ve Mirasyedioğlu (2003) tarafindan yapılan ve lise öğrencilerinin çoğunluğunun matematik dersine ilişkin olumlu tutuma sahip olduklarını gösteren araştırma sonuçlarıyla farklılaşmaktadır. $\mathrm{Bu}$ farklılığın nedeni araştırma örneklemlerinin farklı olmasından kaynaklanabilir. Çünkü Peker ve Mirasyedioğlu (2003) tarafından yapılan araştırma, Ankara ili kapsamında ve 500 lise ikinci sınıf öğrencisi üzerinde gerçekleştirilmiş̧ir. Oysaki eldeki araştırma Türkiye'nin yedi coğrafi 
bölgesini kapsayacak şekilde 14 ilden seçilen ve tüm sınıf düzeylerinde öğrenim gören toplam 30170 öğrenci üzerinde yürütülmüştür.

Türkiye'de öğrenim gören lise öğrencilerinin matematik dersine ilişkin tutumlarının orta düzeyde olduğu bulgusu, liselerde öğrenim gören öğrencilerin matematik tutumlarının yükseltilmesi adına çalışmalar yürütülmesi gerekliliğini akla getirmektedir. Çünkü yapılan bazı araştırmalarda (Ma ve Kishor,1997; Minato ve Kamada,1996) öğrencilerin matematik başarıları ile matematiğe yönelik sahip oldukları olumlu tutumların doğru orantılı olduğu belirtilmektedir. Yani öğrencinin matematik tutumu yükseldikçe derse ilişkin başarıları da yükselmektedir.

Araştırmanın ikinci temel bulgusu, lise öğrencilerinin matematik dersine ilişkin tutumlarını dört faktörün etkilediğini ortaya koymaktadır. $\mathrm{Bu}$ faktörler (1) keyif alma, (2) korku, endişe ve sıkınt1, (3) matematiğin yaşamdaki yeri, önemi ve (4) algılanan akademik başarı olarak isimlendirilmiştir. $\mathrm{Bu}$ faktörler, geliştirilen diğer matematik tutum ölçeklerinde yapılan sinıflamalarla benzerlikler göstermektedir (Aiken, 1974; Adelson ve McCoach, 2011; Aşkar, 1986; Duatepe ve Çilesiz, 1999; Fennema ve Sherman, 1976; Tapia ve Marsh, 2004).

Eldeki araştırmanın üçüncü temel bulgusu ise, lise öğrencilerinin matematik dersine ait tutumlarının cinsiyetlerine göre değişmediğini ancak öğrenim gördükleri coğrafi bölgeye göre anlamlı farklılıklar gösterdiğini ortaya koymaktadır. Yapılan araştırmada liselerde öğrenim gören kız ve erkek öğrencilerin matematik dersine ilişkin tutumları arasında bir farklılık saptanmamıştır. $\mathrm{Bu}$ durum cinsiyetin matematik tutumu ile ilişkisi olmadığını gösteren diğer araştırmalarla (Avcı, Coşkuntuncel ve İnand1, 2011; Farooq ve Shah, 2008; Kaplan ve Kaplan, 2006; Kurbanoğlu ve Takunyac1, 2012; Yenilmez ve Özabac1, 2003) tutarlık göstermektedir. Ancak erkek öğrencilerin matematik tutumlarının kız öğrencilerden daha olumlu olduğunu gösteren çalışmaların (Brandell ve Staberg, 2008; Hoang, 2008; Owiti, 2011; Wilkins ve Ma, 2003) sonuçlarıyla, tam tersi olarak kız öğrencilerin matematik tutumlarının erkek öğrencilerden daha yüksek olduğunu gösteren çalışmaların (Yenilmez, 2007; Özlü, 2001) sonuçları ise eldeki araştırmayla farklılaşmaktadır. Ayrıca araştırmanın bulguları, öğrencilerin yaşadıkları coğrafi bölgenin matematik dersine ait tutumlarını farklılaştırdığgını da göstermektedir. Güneydoğu Anadolu ve Doğu Anadolu bölgelerinde yaşayan lise öğrencilerinin matematik tutumları Türkiye'nin diğer coğrafi bölgelerinde yaşayan lise öğrencilerinin matematik tutumlarından anlamlı şekilde düşük çıkmıştır. $\mathrm{Bu}$ iki bölge gelir dağılımında Türkiye'nin en düşük gelir ortalamasına sahiptir (Filiztekin ve Çelik, 2010; TÜİK, 2008, 2009). Öğrencilerin olumlu matematik tutumuna ve matematikte akademik başarıya sahip olmalarının ekonomik kaynakların 
artışıyla paralellik gösterdiğini belirten çalışmaların (Chiu ve Xihau, 2008; Dinçer ve Uysal, 2010; OECD, 2013) sonuçları ile eldeki araştırmanın sonuçları uyumludur. Uluslararası karşılaştırmalı çalışmalar bir ülkenin eğitime verdiği değerin, öğrencilerinin başarısında en etkili faktör olduğunu göstermektedir (Eccles ve Jacobs, 1986; MacNab, 2000). Bu nedenle, ülke olarak matematik eğitimine hak ettiği değeri vermemiz önem taşımaktadır.

$\mathrm{Bu}$ çalışmada, belirlenen probleme dayalı olarak, toplanan nicel verilerle var olan durumun betimlenmesine çalışılmıştır. Oysa yapılacak yeni araştırmalarla öğrencilerin matematik tutumlarını etkileyen faktörlere ilişkin görüş ve düşüncelerinin nedenleriyle ayrıntılı olarak sorgulandığı nitel araştırmaların yürütülmesi önerilebilir.

\section{KAYNAKLAR}

Adelson, J. L., \& McCoach, D. B. (2011). Development and psychometric properties of the math and me survey: Measuring third through sixth graders' attitudes toward mathematics. Measurement and Evaluation in Counseling and Development, 44(4), 225-247.

Aiken, L. R. (1974). Two scales of attitude toward mathematics. Journal for Research in Mathematics Education, 5(2), 67-71.

Aiken, L. R. (1970). Attitudes towards mathematics. Review of Educational Research, 40, 551-596.

Alkan, V. (2009). The relationship between teaching strategies and styles and pupil's anxiety in mathematics at primary schools in Turkey. Unpublished Doctoral Thesis, University of Nottingham, School of Education, UK.

Aşkar, P. (1986). Matematik dersine yönelik tutumu ölçen Likert tipi bir ölçeğin geliştirilmesi. Eğitim ve Bilim, 11(62), 31-36

Avcı, E., Coşkuntuncel, O. ve İnandı, Y. (2011). Ortaöğretim on ikinci sınıf öğrencilerinin matematik dersine karşı tutumları. Mersin Üniversitesi Ĕgitim Fakültesi Dergisi, 7(1), 50-58.

Baykul, Y. (1987). Matematik ve fen eğitimi yönünden okullarımızdaki durum, Hacettepe Üniversitesi Eğitim Fakültesi Dergisi, 2, 154-168.

Baykul, Y. (1990). Illkokul beşinci slnıftan lise ve dengi okulların son sinfflarına kadar matematik ve fen derlerine karşı tutumda görülen değişmeler ve ögrenci seçme sınavindaki başarı ile ilişskili olduğu düşünülen bazı faktörler. Akara: ÖSYM Yayınları.

Borg, W. R., Gall, J. P., \& Gall, M. D. (1993). Applying educational research: A practical guide. White Plains, N.Y: Longman.

Brandell, G. \& Staberg, E. (2008). Mathematics: a female, male or gender-neutral domain? A study of attitudes among students at secondary level. Gender and Education, 20(5), 495-509.

Büyüköztürk, Ş.(2002) Faktör Analizi: Temel Kavramlar ve Ölçek Geliştirmede Kullanımı. Kuram ve Uygulamada Eğitim Yönetimi, (32), 470-482. 
Büyüköztürk, Ş., Çakmak, E. K., Akgün, Ö. E., Karadeniz, Ş. ve Demirel F., (2008). Bilimsel araştırma yöntemleri. Ankara: Pegem A Yayıncılık

Chiu, M. M., \& Xihua, Z. (2008). Family and motivation effects on mathematics achievement: Analyses of students in 41 countries. Learning and Instruction, 18, 321-336.

Cohen L., Manion L., \& Morrison K. (2008). Research methods in education. N.Y: Routledge, Taylor \& Francis Group.

Creswell, J.W. (2008). Educational research planning, conducting, and evaluating qualitative research (3rd Ed.) N.J: Pearson Education.

Dinçer, M. A., \& Uysal, G. (2010). The determinants of student achievement in Turkey. International Journal of Educational Development, 30(6), 592-598.

Duatepe, A. ve Çilesiz, Ş. (1999). Matematik tutum ölçeği geliştirmesi. Hacettepe Üniversitesi Eğitim Fakültesi Dergisi, 16-17, 45-52.

Eccles, J. S., \& Jacobs, J. E. (1986). Social forces shape math attitudes and performance. Sings, 11(2), 367-380.

Else-Quest, N. M., Hyde, J. S., \& Linn, M. C. (2010). Cross-national patterns of gender differences in mathematics: A meta analysis. Psychological Bulletin, 136(1), 103-127.

Erol, E. (1989). Prevalance and correlates of math anxiety in Turkish high school students. Yayımlanmamış yüksek lisans tezi. Boğaziçi Üniversitesi.

Ethington, C. A., \& Wolfle, L. M. (1986). A structural model of mathematics achievement for men and women. American Educational Research Journal, 23(1), 65-75. Retrieved July 22, 2010, from http://www.jstor.org/stable $/ 1163042$

Farooq, M. S., \& Shah, S. Z. U. (2008). Students' attitude towards mathematics. Pakistan Economic and Social Review, 46 (1), 75-83.

Feather, N. T. (1988). Values, valences, and course enrollment: Testing the role of personal values within an expectancy-valence framework. Journal of Educational Psychology, 80(3), 381-391.

Fennema, E., \& Sherman, J. (1976). Fennema-Sherman Mathematics Attitudes Scales: Instrument desinged to measure attitudes toward the learning of mathematics by females and males. Journal for Research in Mathematics Education, 7(5), 324-326.

Filiztekin, A. ve Çelik, M. A. (2010). Türkiye'de bölgesel gelir eşitsizliği. Megaron, 5(3), 116-127.

Gelbal, S. (1994) $p$ madde güçlük indeksi ile Rasch modelinin b parametresi ve bunlara dayalı yetenek ölçüleri üzerine bir karşılaştırma. Yayınlanmamış Doktora Tezi, Hacettepe Üniversitesi, Sosyal Bilimler Enstitüsü, Ankara.

Hoang, T. N. (2008). The effects of grade level, gender, and ethnicity on attitude and learning environment in mathematics in high school. International Electronic Journal of Mathematics Education, 3(1), 47-59. Retrieved May 11, 2010, from http://www.iejme.com/012008/d3.pdf

İnceoğlu, M. (2010). Tutum algl iletişim (5. Baskl). İstanbul: Beykent Üniversitesi Yayınları. 
Kalayc1, Ş. (2006). SPSS Uygulamalı çok değişkenli istatistik teknikleri. Ankara: Asil Yayın Dağıtım.

Kaplan, A., ve Kaplan, N. (2006). Orta öğretim öğrencilerinin matematik dersine karşı tutumları. Journal of Qafqaz, 17,1-5.

Kurbanoğlu, N. İ. ve Takunyacı, M. (2012). Lise öğrencilerinin matematik dersine yönelik kaygı, tutum ve özyeterlik inançlarını cinsiyet, okul türü ve sınıf düzeyi açısından incelenmesi. Uluslararası İnsan Bilimleri Dergisi, 9(1), 110130.

Ma, X. (1997). Reciprocal relationships between attitude toward mathematics and achievement in mathematics. The Journal of Educational Research, 90 (4), 221-229. Retrieved November 18, 2009, from http://www.jstor.org/stable/ 27542096.

Ma, X., \& Kishor, N. (1997). Assessing the relationships between attitude toward mathematics and achievement in mathematics: A meta-analysis. Journal for Research in Mathematics Education, 28(1), 26-47. Retrieved November 18, 2009, from http://www.jstor.org/stable/749662.

MacNab, D. (2000). Raising standards in mathematics education: Values, vision, and TIMSS. Educational Studies in Mathematics, 42(1), 61-80.

MEB (2009). İlköğretim matematik dersi 6-8. sınıflar öğretim programı. MEB Talim ve Terbiye Kurulu Başkanlığı, Ankara.

Meece, J. L., Wigfield, A., \& Eccles, J. S. (1990). Predictors of math anxiety and its influece on young adolescents' course enrollment intentions and performance in mathematics. Journal of Educational Psychology, 82(1), 60-70.

Minato, S., \& Kamada, T. (1996). Results of research studies on causal predominance between achievement and attitude in junior high school mathematics of Japan. Journal for Research in Mathematics Education, 27(1), 96-99. Retrieved July 24, 2010, from http://www.jstor.org/stable/749200.

Mulhern, F., \& Rae, G. (1998). Development of a shortened form of the FennemaSherman mathematics attitudes. Educational and Sychological Measurement, 58(2), 295-306.

Muzzatti, B., \& Agnoli, F. (2007). Gender and mathematics: Attitude and stereotype threat susceptibility in Italian children. Developmental Psychology, 43(3), 747759.

OECD (2013). PISA Results: Ready to learn - Students' engagement, drive and selfbeliefs. (Volume III), PISA, OECD Publishing.

Owiti, D. S. O. (2011). Students' sex and attitudes toward mathematics: A case of secondary school students in Eldoret municipality, Uasin Gishu district, Kenya. International Journal of Educational Research and Technology, 2(2), 56-61.

Özlü, Ö. (2001). Ortaöğretim öğrencilerinin matematiğe karşı tutumları. Yayınlanmamış Yüksek Lisans Tezi, Marmara Üniversitesi, Fen Bilimleri Enstitüsü, İstanbul.

Patton, M. Q. (2002). Qualitative research and evaluation methods (3rd ed.). Thousand Oaks, CA: Sage Publication. 
Peker, M. ve Mirasyedioğlu, Ş. (2003). Lise 2. sınıf öğrencilerinin matematik dersine yönelik tutumları ve başarıları arasındaki ilişki. Pamukkale Üniversitesi Ĕ̈itim Fakültesi Dergisi, 14, 157-166.

Perry, A. B. (2004). Decreasing math anxiety in college students. College Student Journal, 38(2), 321-324.

Quinn, B., \& Jaday, A. D. (1987). Causal relationship between attitude and achievement for elementary grade mathematics and reading. Journal for Educational Research, 80(6), 366-372.

Sümbüloğlu, K. ve Sümbüloğlu, V. (1993). Biyo İstatistik, Ankara: Özdemir Yayıncilık.

Tan, Ş. (2008). Eğitimde ölçme ve değerlendirme: KPSS el kitabı. Ankara: PegemA Yayıncilik.

Tapia, M., \& Marsh, G. E. (2004). An instrument to measure mathematics attitudes. Academic Exchange Quarterly, 8(2), 16-21.

TÜIK (2008). Türkiye İstatistik Yılllğı 2007. Ankara: TÜIK Matbaası.

TÜIK (2009). Türkiye İstatistik Yıllı̆̆ 2008. Ankara: TÜIK Matbaası.

Wilkins, J. L. M., \& Ma, X. (2003). Modeling change in student attitude toward and beliefs about mathematics. The Journal of Educational Research, 97(1), 52-63.

Yenilmez, K. (2007). Attitudes of Turkish high school students toward mathematics. International Journal of Educational Reform, 16(4), 318-335.

Yenilmez, K. ve Özabacı, N. Ş. (2003). Yatılı öğretmen okulu öğrencilerinin matematik ile ilgili tutumları ve matematik kaygı düzeyleri arasındaki ilişki üzerine bir araştırma. Pamukkale Üniversitesi Eğitim Fakültesi Dergisi, 14(2), 132-146.

Zan, R., \& Di Martino, P. (2007). Attitude toward mathematics: Overcoming the positive 7 negative dichotomy. The Montana Mathematics Enthusiast, 3, 157168. 